\title{
Marine protected areas and artificial reefs: A review of the interactions between management and scientific studies
}

\author{
Joachim Claudet $^{1,2, a}$ and Dominique Pelletier ${ }^{2}$ \\ 1 EPHE, UMR 8046 CNRS, 52 avenue Paul Alduy, 66860 Perpignan Cedex, France \\ 2 Laboratoire MAERHA, IFREMER, rue de l'Ile d'Yeu, BP 21105, 44311 Nantes Cedex 03, France
}

Received 17 September 2003; Accepted 29 April 2004

\begin{abstract}
Inshore marine areas host key habitats for the biological cycle of many marine populations, but are subject to strong anthropogenic pressure. Uses of inshore areas are multiple and often give rise to conflicting interests. In this context, marine protected areas (MPAs) and artificial reefs (ARs) are increasingly regarded as interesting management measures, in that they contribute to ecosystem conservation, fisheries sustainability, and because they can be helpful in zoning coastal areas in order to reduce conflicts between users. Beyond these expected benefits, it is important to appraise whether MPAs and ARs meet managers' objectives. This review focuses on the interaction between ecological sciences and management in the purpose of establishing or monitoring MPAs and ARs. We first study how objectives have to be formalized through management plans, and which kinds of information need to be collected in this respect. We then report management objectives related to MPAs and ARs, and list corresponding observed effects. Finally, we discuss the present role of monitoring and scientific research in the management process and propose a few perspectives for scientific research.
\end{abstract}

Key words: Marine protected areas / Artificial reefs / Fish / Impact assessment / Management / Management actions objectives / Monitoring

\begin{abstract}
Résumé - Aires marines protégées et récifs artificiels : une synthèse des interactions entre gestion et études scientifiques. Les zones côtières abritent des habitats-clés pour le cycle biologique de nombreuses populations marines, mais sont soumis à une forte pression anthropique. Les usages de la bande côtière sont multiples et occasionnent souvent des conflits d'intérêts. Dans ce contexte, les aires marines protégées (AMP) et les récifs artificiels (RA) sont de plus en plus considérés comme des mesures de gestion pertinentes dans la mesure où ils contribuent à la conservation de l'écosystème, au maintien des pêcheries, et parce qu'ils peuvent être utiles pour allouer l'espace côtier entre usagés et pour réduire certains conflits. Au-delà de ces bénéfices attendus, il est important d'évaluer si les AMP et les RA satisfont les objectifs des gestionnaires. Dans cette synthèse bibliographique, nous nous intéressons, en particulier, aux interactions entre les sciences écologiques et la gestion concernant l'établissement ou le suivi des AMP et RA. Nous étudions, en premier lieu, comment les objectifs doivent être formalisés au travers des plans de gestion, et quels types d'information sont ainsi nécessaires à collecter. Nous présentons ensuite les objectifs de gestion en relation avec les AMP et les RA, et les effets observés correspondants. Enfin, nous discutons du rôle des suivis scientifiques et de la recherche dans le processus de gestion et proposons quelques perspectives de recherche.
\end{abstract}

\section{Introduction}

Inshore marine areas, in particular shallow shelf areas, host key habitats for the biological cycle of many marine populations. At the same time, they are subject to strong anthropogenic pressure. Inshore uses have deeply evolved these last decades and most resources are now being overexploited (Lauck et al. 1998; Castilla 2000), raising doubts as to fisheries sustainability (Murray et al. 1999; Pauly et al. 2002). In order

\footnotetext{
a Corresponding author: joachim.claudet@ifremer.fr
}

to protect and restore biological resources, implementation of new measures or adaptations of existing management measures have become urgent at both local and regional scales. Because most fishing activities, either commercial or recreational are practiced in specific and sometimes small inshore areas, Marine Protected Areas (MPAs) and Artificial Reefs (ARs) have been envisaged as potentially interesting tools to deal with the availability and accessibility of marine resources (White et al. 1990). A MPA is defined as "any area of the intertidal or subtidal terrain, together with its overlying water and associated flora, fauna, historical and cultural features, which 
has been reserved by law or other effective means to protect part or all of the enclosed environment" (IUCN 1988). An AR is defined as "any material or matter deliberately placed in an area of the marine environment where that structure does not exist under natural circumstances for the purpose of protecting, regenerating, concentrating or increasing populations of living marine resources, or for enhanced recreational use of the area" (Anonymous 2003).

In the last decade, MPAs and ARs have become quite popular (Jones et al. 1993; Cocklin et al. 1998; Pomeroy 1999; Halpern 2003), and it is now important to establish to what extent they have met managers' objectives. The U.S. Congress' Executive Order 13518 on MPAs (May 26, 2000) called for the development of "practical, science-based criteria and protocols for monitoring and evaluating the effectiveness of MPAs". This is also a need for ARs. Ecosystem monitoring programs, and associated indicators have been set up in this purpose, but existing assessments are often not sufficiently formalized for managers and administrators, in that they may not take into account initial management objectives (Bohnsack and Sutherland 1985; Attwood et al. 1997a,b; Lindberg 1997; Steimle and Meier 1997; Alder et al. 2002; Jensen 2002a,b). In addition, these programs are often found to be too expensive. As underlined by Roberts and Polunin (1993), "there is now a critical need for designed studies of management rather than the ad hoc approaches adopted to date". Such focused studies are now being undertaken (Hockings et al. 2000; Seaman 2002; Ehler 2003).

In this article, we reviewed the literature on management and scientific studies on MPAs as well as on ARs, being particularly interested in their common points. We focused on the interaction between ecological science and management in the purpose of establishing or monitoring MPAs and ARs. Cultural and economic aspects will not be extensively dealt with, as we are mainly interested in biological resources, but these aspects obviously contribute to the definition of many management goals.

We first studied how objectives were formalized through management plans, and which kind of information needs to be collected in this respect. We then reported management objectives related to MPAs and ARs, and confronted them with the effects effectively observed. Finally, we discussed the role of monitoring and scientific research in the management process and proposed a few perspectives for scientific research.

\section{Goal-setting and management expectations to assess}

For establishing effective MPAs and ARs programs, realistic goals based on management objectives must be specified. Consequently objective elaboration or goal-setting procedures that account for multiple uses and several management objectives first have to be developed.

\subsection{Specific goal setting: A participative process}

According to Pomeroy (1999), it may be more important to consider both ecological and economic aspects rather than only ecosystem preservation. MPA benefits should then be considered in terms of trade-offs between long-term protection of ecological resources and medium and short-term economic benefits. ARs effects linked to production are medium to long term, habitat protection benefits being more immediate. However, this is not straightforward because it is difficult to value the profitability of some medium-term ecological effects or to assess non-monetary benefits that users can assign to resources. In addition, contradictory interests between conservation and exploitation represent a major constraint in resource allocation exercises (Beaumont 1997; Sumaila et al. 2000), and may lead to conflicts between different user groups. In this respect, a resource-use analysis is deemed necessary in zoning and management plans. Jameson et al. (2002) suggested a management based on a business plan approach. The business planning process can be understood as the link between two processes: strategic planning and operational planning. This kind of approach could be helpful for an integrated management through the understanding of the relationships between environmental and economic processes able to bring economic returns.

Beyond the long-term ecological and short-term economic trade-offs, the successful design, development and management of ARs or MPAs should involve all interested groups of people in a multi-disciplinary and co-management approach (White et al. 1990; Attwood et al. 1997a,b; Beaumont 1997; Cocklin et al. 1998; Pomeroy 1999; Shafer 1999). There is a need to associate main users to such projects early in the decision process, and in particular fishermen (Pomeroy 1999). This is also true for local administration involved in regional planning to control potentially harmful human activities, outside the protected area or around ARs, that could impact both populations and habitats (Rogers and Beets 2001; Salmona and Verardi 2001).

To develop participative approaches, all user groups must be identified. In the case of AR projects, knowing the actual users that will benefit from ARs will help to choose the appropriate design (Bombace 1989). Participants in the management process are defined as "groups of people with common objectives and sets of interests with regard to the resource in question and the environment" (Grimble and Chan 1995). In a second step, primary, secondary and external participants may be distinguished, according to their influence on the decision process. Then, socio-economic and political interactions between user groups have to be carefully analyzed. Decision processes can then proceed. For instance, Brown et al. (2001) used a multi-criteria analysis in order to increase participation in the decision process, and to develop consensus-based approaches for management. A multi-criteria analysis allows attributing scores to criteria that should be accounted for, but are difficult to measure quantitatively.

In addition, the links between coastal and terrestrial activities make it necessary to integrate MPAs and ARs in general environment management and conservation strategies. Management of ARs and MPAs should be consistent with fisheries management, e.g. to avoid stock overexploitation through unexpected reallocation of fishing effort over space, at MPA borders or around ARs (Polovina 1991; Bohnsack 1996; Grossman et al. 1997; Murray et al. 1999; 
Botsford et al. 2003; Denny and Babcock 2004). In particular, the integration of MPA and AR projects with Essential Fish Habitats (EFH) initiatives could contribute to link coastal management and fisheries management (Polovina 1991; Lindeman et al. 2000). EFH are defined as "those waters and substrate necessary to fish for spawning, breeding, feeding, or growing to maturity" (NOAA 1996).

Once stakeholders and managers have stated management objectives, they should be formalized for scientists and for other stakeholders including users.

\subsection{Formalizing management expectations}

In conventional management, decision processes are described according to three different steps: problem identification, possible evolutions under a range of actions, and selection of action among available choices (Janssen 1994 in Brown et al. 2001). Therefore, the information concerning the objectives of the MPA and AR projects is crucial (Attwood et al. 1997b; Shafer 1999). It should be noted that this information is more societal than scientific. This procedure is critical in that it allows formalizing management expectations, to define effective designs, and to build targets against which progresses of MPAs and ARs can be assessed (Steimle and Meier 1997; Bain et al. 2000). Without a clear framework for management, objectives for monitoring are likely to be unclear, which is bound to hinder monitoring programs. Unclearly stated or ambiguous objectives may lead to the measurement of wrong variables in the monitoring process (Dale and Beyeler 2001).

Following appropriate specifications, a management plan may then be developed from these specifications. Objectives including conservation, scientific research and education should be formally stated in the management framework even if they might change with time (Kelleher and Kenchington 1992; Attwood et al. 1997a,b). Once management objectives and expectations are clearly specified, biologists, and ecologists, as well as scientists from other domains, can together be helpful to identify the important steps and prioritize them (Shafer 1999). This should in principle lead to effective MPAs and ARs (White et al. 1990; Seaman 1996; Steimle and Meier 1997; Agardy 1999).

To assess whether objectives are reached or not, the plan must then include a monitoring program (Attwood et al. 1997a,b; Bohnsack et al. 1997; Steimle and Meier 1997; Halpern 2003). This program could also be used to inform the public about the evolution of the MPA and AR. In the case of ARs, Baine (2001) pointed out a lack of information from managers about property rights, responsibility, regulation, conflicts between users, environmental evaluation, and more generally concerning the need for long-term management.

\section{Objectives and observed effects}

\subsection{Marine protected areas}

Many authors stated general objectives for MPA establishment, focusing on some specific fields; e.g. ecological implications (Jones et al. 1993; Agardy 1998, 1999; Harmelin 2000), fisheries implications (Bohnsack 1993, 1996; Agardy 2000a; Botsford et al. 2003), educational implications (Meinesz et al. 1983; Konovalov 1991) or social and economic implications (Cocklin et al. 1998; Badalamenti et al. 2000; Carter 2003).

From this literature MPA objectives were synthesized as follows: (1) conservation and protection of natural resources in areas that are recognized as particularly important in terms of ecological diversity to ensure their long-term viability and to maintain their genetic diversity or to allow populations to recover to their pristine level; (2) restoration of damaged or over-exploited areas considered as critical to the survival of such species, or of significance for the life cycles of economically important species; (3) improvement of the relationship between man, his environment, and economic activities, by maintaining traditional uses and the sustainable exploitation of resources, by preventing outside activities from detrimentally affecting the MPA, and by protecting and managing historical, cultural and aesthetic sites; (4) improvement of fishing yields, by protecting spawning stock biomass, by acting as a source of recruited and post-recruited stages for surrounding areas, by restoring the age structure of natural populations, and by acting as an insurance against mismanagement in fishing areas; (5) resolution of present or anticipated conflicts between coastal area users; (6) improvement of knowledge about marine environment by dealing with research and educational aspects; and (7) valuation of heritage for the local administration through tourism and economic profitability for the residents. Boersma and Parrish (1999) estimated from a literature survey that the main reasons for establishing MPAs were marine environment protection ( $93 \%$ of the papers), biodiversity maintenance and tourism promotion (67\%) and fisheries management $(53 \%)$. Research and education were secondary objectives.

Objectives previously quoted correspond to theoretical expectations. But in the literature what kind of ecological and biological effects were indeed observed after establishment of MPAs? Many authors listed observed ecological benefits for fish populations (e.g. Bell 1983; Alcala and Russ 1990; García-Rubies and Zabala 1990; Roberts and Polunin 1993; Francour 1994; Dufour et al. 1995; Harmelin et al. 1995; Attwood et al. 1997a; Agardy 1998; Allison et al. 1998; Boersma and Parrish 1999; Caddy 2000; Francour et al. 2001; Lubchenco et al. 2003). There exist several reviews about this subject, Halpern (2003) being the most recent. Few general conclusions about the ecological effects of MPAs may be drawn from these studies. Obviously, the vast majority of exploited fish species displays increases in abundance, biomass and/or mean size when protection is effective. Jones et al. (1993) claimed that this is true whatever the age or size of the reserve; but some studies show that this reserve effect is tied to the age of the MPA (Russ and Alcala 1996). At a regional scale, MPAs can be an efficient conservation tool only if they are representative of all biogeographic areas (Boersma and Parrish 1999; Airamé et al. 2003; Benedetti-Cecchi et al. 2003). In many studies, ecological effects were not found to be significant, in relation with low statistical power or the lack of an appropriate experimental design (Fraschetti et al. 2002; Russ 2002). 


\subsection{Artificial reefs}

Several objectives tied to the establishment of ARs pertain to conservation and biodiversity or ecological knowledge (Bohnsack and Sutherland 1985; Ardizzone et al. 1996; Barnabé et al. 2000), to habitat protection (Polovina 1991; Pickering et al. 1998; Ramos-Esplà et al. 2000), to fisheries enhancement (Nakamura 1985; Samples and Sproul 1985; Polovina 1991; Bohnsack et al. 1994), and to economy profitability (Whitmarsh and Pickering 1995, 1997). They can be stated as follows: (1) to increase fish biomass, by providing shelter from fishing; (2) to increase fauna diversity, by providing new habitats; (3) to reduce detrimental impacts on existing habitats, through trawl exclusion, and to restore damaged habitats; (4) to improve cost-effective fishing practices, by reducing displacement costs for nearby coastal fleets; (5) to reduce conflicts between inshore and offshore fleets; (6) to provide economic benefits, through fisheries or diving activities; and (7) to improve knowledge on colonization processes. According to Bohnsack and Sutherland (1985) and Bohnsack et al. (1994), the primary goal of ARs is to ensure fisheries' sustainability.

Ecological effects of ARs are well documented (Bohnsack and Sutherland 1985; Ambrose and Anderson 1990; White et al. 1990; Bohnsack 1991; Bohnsack et al. 1994; Bombace et al. 1994; Santos et al. 1995a,b, 1996; Grossman et al. 1997; Charbonnel et al. 2000, 2002; Zalmon et al. 2002). In most cases, higher abundances, densities, and biomasses were found close to ARs compared to undisturbed natural control areas, even when community structures are quite similar (Ody and Harmelin 1994). Note that differences in community structure might be due to a higher structural complexity on AR compared to natural temperate reefs, while in the case of MPAs, such differences may be attributed to protection. Also, ARs that are in areas not protected from fishing seem to display a refuge effect (Charbonnel et al. 2000). Whether ARs act more as fish aggregation devices or by actually contributing to increased fish abundance has not been demonstrated yet.

The immersion of ARs around MPA borders can also protect the area from illegal trawling activities. In the Côte Bleue Marine Park (French Northwestern Mediterranean), illegal inshore trawling substantially decreased following AR immersions (Harmelin 2000).

In summary, observed effects of MPAs and ARs mostly pertain to differences in abundance and mean size between the MPA/AR and comparable control areas, and to differences in fish yield at MPA border and around ARs. However, there appears to be a gap between management objectives stated in very general terms, a number of expected ecological effects, and in fine relatively few significant results in published scientific studies. As such, it is difficult to deduce from these effects that the general objectives listed above were reached.

\section{Place and role of monitoring and research studies in the management process}

The literature reviewed showed that management of MPAs and ARs should be an important component of coastal management, that it needs a comprehensive knowledge of the ecosystems to protect, and that MPA and AR impacts should be routinely monitored. In management activities, the respective roles of scientific monitoring and research have to be distinguished. Monitoring has to be understood as a set of actions that permits impact assessment directly related to managers' expectations. It is generally undertaken or supervised by scientists. In contrast, research programs aim at improving ecosystem knowledge and understanding. It hence seems desirable to design scientific projects that integrate on the one hand routine monitoring in cooperation with managers, and on the other hand, academic research projects aimed at improving knowledge and understanding of ecosystem dynamics (Allison et al. 1998).

\subsection{Scientific monitoring and management}

A monitoring program is a program that organizes, controls and adapts a set of operations ranging from collection of field data to data-processing for impact assessment. It should be used for a sound management of MPAs and ARs, to assess whether they meet management objectives, and to possibly adapt their design to increase their production or conservation potential (Allison et al. 1998; Dale and Beyeler 2001).

Francour et al. (2001) advocated a stronger cooperation between users, managers and scientists. For example, monitoring fish populations through simple measures of fish abundance e.g. presence/absence of common species (Harmelin 1999) could facilitate the participation of coastal area users. Aubert (1991) stressed that politicians, administrators and marine environment scientists should: (1) participate to the collection of information and data on ecological, scientific and administrative aspects in the areas of interest; (2) give advice on the evolution and management of these areas; and (3) suggest common actions for their scientific and economic promotion. Monitoring of marine populations should be facilitated by such cooperation programs, in that all relevant information whether ecological, socio-economic or from management would be gathered in a common database in order to be used to monitor the efficiency of MPAs and ARs, and to consequently adapt management (Blankenship and Leber 1995; Schwartz 1999; Jensen 2002a; Seaman 2002). This kind of tool for the management of coastal ecosystems is for instance an objective of the SysCoLag (Coastal and Lagoon Systems) Programme of the Languedoc-Roussillon Region in the French Mediterranean started in 2003.

A large proportion of management plans for MPAs or for ARs were not implemented, and no monitoring or evaluation program was planned upon their creation (Kelleher 1996; Attwood et al. 1997b; Baine 2001). Among other examples, the Goukamma Marine Reserve in South Africa does not have a regular monitoring strategy, although the Scientific Service Division of the Cape Nature Conservation provides scientific expertise to support conservation programs in the Western Cape Province (Attwood et al. 1997b). In Victoria (Australia), the initial selection of MPAs was not based on ecological criteria because of a lack of knowledge. Now, initiated by the Victorian government and chaired by the Department of Natural Resources and Environment (2001), a program have been established to assess long-term changes in marine biodiversity 
on shallow water rocky reefs. In contrast, scientific committees guide research and monitoring undertaken in many MPAs such as the Côte Bleue Marine Park (French Northwestern Mediterranean). In the Philippines, the AR program, supervised by the Department of Agriculture, serves as a mean for disseminating information on resource management and conservation. Examples are numerous and are only provided for illustrating the diversity of monitoring situations relative to MPAs and ARs.

To improve knowledge about species dynamics, the management of MPAs or ARs should be actively adaptive in order to react to non predicted changes in the ecosystem or in its uses (Palumbi 2002). In practice, monitoring programs should include control areas so that rigorous hypothesis testing can take place, and it may use a variety of options, among which the possibility of selective fishing that would reduce unexpected predation or competition between species (Agardy 2000 b). To facilitate such processes, prioritizing target species and developing an approach based on the whole fish community are helpful to management decisions, in particular when conservation and restoration of populations is a primary objective (Blankenship and Leber 1995). Prioritizing is all the more necessary since the implementation of a MPA or an AR may have positive impacts on some species and negative impacts on others, as shown in the case of MPA by empirical or modeling studies (e.g. St-Mary et al. 2000). In these conditions, a diagnosis of the overall performance of the MPA or AR is necessary.

\subsection{Scientific research and management}

Some managers or scientists may think that MPAs afford protection for all resident species, with no need for further management of the species within and outside the MPA or around the AR. In this respect, a sound knowledge of species dynamics may appear unnecessary. But avoiding mismanagement requires research (Shafer 1999). In order to support the management of MPAs or ARs according to the particular needs of each area, science must provide strategic information, i.e. basic fundamental knowledge about the ecosystems of interest.

Contrary to terrestrial ecosystems, marine ecosystems are characterized by the lack of boundaries attached to ecological processes and to factors influencing those processes. Knowledge about the dispersal schemes and the geographical range of the populations should be accounted for in management measures (Agardy 2000b; Barnabé et al. 2000). In addition, these measures should be tailored to each specific situation (Shafer 1999; García-Charton 2000; Planes et al. 2000).

Hence, even if positive MPA effects have been observed for sessile organisms, as well as for highly mobile species (e.g. bull kelp and snapper - Babcock et al. 1999), fish behaviour can affect reserve function (Kramer and Chapman 1999). Mobile species can also adapt their behaviour as a result of the reservation or as a function of the distance between one AR and another or between ARs and adjacent natural areas. Fish behaviour can also change in answer to the presence of divers (Jones et al. 1993; Jouvenel and Pollard 2001). Knowledge on life cycles and species dynamics are also required.
Habitat requirements, fish movements and behaviour, relationships between subpopulations, larval dispersal schemes and reference points for stock replenishment are specific to each species and have to be identified to effectively protect target species (Rowley 1994; Blankenship and Leber 1995; Guénette et al. 1998; Guénette and Pitcher 1999; Pelletier 2001; Neigel 2003), so as to anticipate density-dependent sideeffects (Sánchez-Lizaso et al. 2000). Actually, variations in community structure can emerge due to changes in the food web after AR immersion (Barnabé et al. 2000) or after MPA implementation (Jones et al. 1993). Increases in predator abundance may result in decreases in prey abundance as a consequence of trophic cascades (Pinnegar et al. 2000). Babcock et al. (1999) showed that changes in community structure indicated a higher trophic complexity and increased primary and secondary productions within the MPA. Similar results on AR were observed, primary production and nutrient concentration being much higher around the AR than in a comparable control area (Branden et al. 1994). But, few studies showed how and to which extent this primary production is transferred into productivity or biomass.

Many papers used population dynamics models to understand the potential impact of MPAs or ARs on ecosystem and fisheries (e.g. Botsford et al. 2003; Gerber et al. 2003). Polacheck (1990) used a yield-per-recruit model to explore the consequences of MPAs on a exploited fish population. Catch increased for species with intermediate movement rates. Polovina and Sakai (1989) modeled catch per unit effort (CPUE) to demonstrate the potential benefits of ARs. Other population dynamics models included reproduction in addition to growth and mortality in the context of MPAs (Rijnsdorp and Pastoors 1995; Apostolaki et al. 2002) or ARs (Harmelin and Bellan-Santini 1996; Pitcher and Seaman 2000). Community models based on trophic relationships (Fang 1992; Pauly 1998; Walters et al. 1999; Pitcher et al. 2000, 2002; Pitcher and Seaman 2000; Watson et al. 2000) or on competition and density-dependent processes (Osenberg et al. 2002) were also used to study AR effects. Gerber et al. (2002) examined MPA efficiency as a function of life cycles, fishing pressure and reserve size. They founded that MPAs could be effective in preventing species extinction and in increasing species density, but that they rarely lead to increases in fishing yield.

Studying MPAs and ARs can also be useful to test hypotheses at the ecosystem level, such as trophic relationships (Bohnsack and Sutherland 1985; Polovina 1991; Allison et al. 1998; Harmelin 2000).

ARs used in conjunction with a MPA may be an important tool for improving our understanding of the ecology of coastal fish communities and to study the efficiency of the MPA through resulting changes in the ecosystem (Barnabé et al. 2000). ARs immersion within the MPA could have other positive aspects. Caddy (2000) suggested two ways to increase MPA efficiency when fishing pressure is high; either by an increase of the surface area protected or by an increase of its holding capacity. This last can be reached by use of ARs. Hence, the study of AR effects could improve the understanding of MPA effects (Bohnsack 1991). ARs are also helpful to study the relationship between habitat complexity and spatial distribution of fish. 


\section{Perspectives for scientific studies and monitoring}

Some of the topics mentioned in the previous section are not yet well known and deserve further investigations Which may benefit to management of MPAs or ARs.

Like many other authors (e.g. Bohnsack 1989; Kelleher and Kenchington 1992; Allison et al. 1998; Botsford et al. 1999) we claim that detailed knowledge on the biology, ecology and life cycles of species to be protected or colonizing the reefs is essential for an appropriate design of MPA and AR, as well as for their monitoring. This includes in particular knowledge about the spatial distribution and movements of populations, reproduction features and larval dispersion schemes. The efficiency of MPAs and ARs at restoring or improving fish biomass largely depends on fishing exploitation, and the evaluation of the natural and fishing mortality of fished populations is crucial (Baine 2001; Côté et al. 2001). Population dynamics should be closely linked with the oceanographic conditions, and in relation to possible pollution (e.g. dispersion and intensity of pollutant, scale of MPA or AR with respect to extent of the threat). Some authors deem that current intensity and direction are more influential on fish abundance in the AR, than design features e.g. reef size or refuge number (Grossman et al. 1997). Tuya et al. (2000) proposed additional information to be measured for future research including quantification of human activities dynamics, measurement of biogeographic characteristics, atmospheric and oceanographic parameters, and water quality. Better attention should also be given to the collection of social, cultural and economic data in the process of establishing and monitoring MPA and AR (Kremen et al. 1999; Pomeroy 1999).

Regarding habitat, reviewed studies (in relation with the lack of initial assessment) do not allow to conclude whether an apparent increase in habitat quality is linked to protection from detrimental uses or to the initial features of the reserved area. Natural variability can result in biased interpretations if it is not properly taken into account (Underwood 1981, 1993; Underwood 2003). Habitat heterogeneity and the hierarchical organization of habitats constrain the design of studies on AR ecological effects (Jensen et al. 2000; Ody and Harmelin 1994) and on MPA (Lasiak 1998; García-Charton and Pérez-Ruzafa 1999; García-Charton et al. 2000, 2004). It is thus necessary to monitor habitat characteristics at the same time as fish communities.

The scale of management dictates the spatial and temporal scales for information used in monitoring design (Ward et al. 1999). Without an adequate long-term monitoring and scientific study it is difficult to conclude about the efficiency of MPAs or ARs (Bohnsack and Sutherland 1985; White et al. 1990; Steimle and Meier 1997; Done and Reichelt 1998; Castilla 2000; García-Charton et al. 2000, 2004). The effects of MPAs and ARs on fish populations depend on the scales considered (Bohnsack 1991; Polovina 1991; Carr and Hixon 1997). For example, in the case of a reserve network, species diversity can decrease within each marine reserve and distinct communities can emerge, leading to an overall increase in diversity (Hockey and Bosman 1986). Fish abundance can increase in a limited area surrounding an AR, while changes in abundance are not observed on a larger scale (Bohnsack 1991).
Similarly, if the studied scale is too local, biological effects on fish stocks may be impossible to detect (Polovina 1991). One recommendation consists in choosing, in an adequate manner, the spatial and temporal scales of the studies with nonarbitrary operational methods (Bohnsack and Bannerot 1986; Benedetti-Cecchi 2001). With regard to MPAs and according to Schwartz (1999), it is necessary to consider conservation at two scales: the fine-filter scale (genes, populations, species) and the coarse-filter scale (communities, habitats, ecosystems, landscapes). In addition, Ardizzone et al. (1996) believed it is important to consider genetic, phylogenetic and ecological scales; each scale requiring specific studies. Ideally, monitoring programs should account from the genetic level to the landscape level (Blankenship and Leber 1995).

The evaluation of MPA and AR effects implies the development of rigorous statistical procedures for detecting effects at several temporal and spatial scales, which stresses the need to improve empirical and analytical approaches (Murray et al. 1999; Benedetti-Cecchi 2001). It is important to collect data before the reservation or the AR immersion (BACI, Before and After Control Impact) to avoid confusion over the effects (Roberts and Polunin 1991; Underwood 1992; Carr and Hixon 1997). The impacts of MPAs and ARs can be monitored after their establishment (ACI, After Control Impact) if control points are numerous enough to allow a comparison with the impacted site (Carr 2000). Following Underwood (1992) and Chapman et al. (1995), control sites must: (i) be unaffected by the impact under study (in this case MPA or AR); (ii) exhibit habitats and communities similar to the impact area (MPA or AR); (iii) be chosen at a spatial scale covering the dispersal of the sampled populations; and (iv) range from local to regional distributions when protection efficiency is known.

\section{Conclusion}

Mangel (2000) pointed out that rather than managing ecosystems, management deals with human interventions in ecosystems. Managing MPAs and ARs need a good understanding of the objectives for which they are established. Expected ecological effects are multiple but only a few were evidenced by appropriate experiments. Such results can still have a heuristic value for the stakeholders in the goal-setting process. Goal-setting should be based on a participative approach with users or local communities that may possibly lead to the definition of new social, economic, or political objectives. These management expectations have then to be formalized and prioritized in a management plan including monitoring programs. In the whole process, science must provide strategic information to back monitoring programs and to help managers in specifying and formalizing their expectations and position. However, there is a lack of knowledge in several important scientific domains. Scientific studies have to focus on ecosystem variability, on the scales to be considered and the appropriate experimental designs to reveal representative results. Ultimately, the success of a MPA or an AR, as said by Baine (2001), will "reflect the quality of the prior planning and ongoing management". 
Acknowledgements. This study is part of the Programme Systèmes Côtiers et Lagunaires (SysCoLag), funded by the Region LanguedocRoussillon (Contrat de Plan Etat/Région 2000-2006). This work was made possible through joint financial support from SysCoLag and from IFREMER funding for the $\mathrm{PhD}$ thesis of Joachim Claudet. The authors thank Tundi Agardy and an anonymous reviewer for their most helpful comments on an earlier draft of this article.

\section{References}

Agardy T., 1998, Global trends in marine protected areas. In: Trends and future challenges for U.S. national ocean and coastal policy, Trends in managing the environment, pp. 51-55.

Agardy T., 1999, Global experiences in marine protected area planning and lessons learned. In: Series, C.W. (Ed.), Scientific design and monitoring of Mediterranean marine protected areas. CIESM, 16 boulevard de Suisse, MC-98000, Monaco, Porto Cesaro - Italy, Vol. 8, pp. 17-19.

Agardy T., 2000a, Effects of fisheries on marine ecosystems: A conservationist's perspective. ICES J. Mar. Sci. 57, 761-765.

Agardy T., 2000b, Information needs for marine protected areas: Scientific and societal. Bull. Mar. Sci. 66, 875-888.

Airamé S., Dugan J.E., Lafferty K.D., Leslie H., McArdle D.A., Warner R.R., 2003, Applying ecological criteria to marine reserve design: A case study from the California Channel Islands. Ecol. Appl. 13, S170-S184.

Alcala A.C., Russ G.R., 1990, A direct test of the effects of protective management on abundance and yield of tropical marine resources. J. Cons. Int. Explor. Mer. 46, 40-47.

Alder J., Zeller D., Pitcher T.J., Sumaila U.R., 2002, A method for evaluating marine protected area management. Coast. Cons. 30, 121-131.

Allison G.W., Lubchenco J., Carr M.H., 1998, Marine reserves are necessary but not sufficient for marine conservation. Ecol. Appl. 8, S79-S92.

Ambrose R.F., Anderson T.W., 1990, Influence of an artificial reef on the surrounding infaunal community. Mar. Biol. 107, 41-52.

Anonymous, 2003, Policy Statement of the National Marine Sanctuary Program: Artificial Reef Permitting Guidelines. http://www. sanctuaries.nos.noaa.gov/library/ national/arpolicy071503.pdf, p. 45.

Apostolaki P., Milner-Gulland E.J., McAllister M.K., Kirkwood G.P., 2002, Modelling the effects of establishing a marine reserve for mobile fish species. Can. J. Fish. Aquat. Sci. 59, 405-415.

Ardizzone G.D., Somaschini A., Belluscio A., 1996, Biodiversity of European artificial reefs Proceedings of the 1st Conference of the European Artificial Reef Research Network, Ancona, Italy, pp. 39-59.

Attwood C.G., Harris J.M., Williams A.J., 1997a, International experience of marine protected areas and their relevance to South Africa. S. Afr. Mar. Sci. 18, 311-332.

Attwood C.G., Mann B.Q., Beaumont J., Harris J.M., 1997b, Review of the state of marine protected areas in South Africa. S. Afr. Mar. Sci. 18, 341-367.

Aubert M., 1991, Aspects internationaux pour la création de parcs marins. Côtes et parcs marins de la Méditerranée $-4^{\mathrm{e}}$ Colloque International, 30 May - 1 June 1991, Bastia, Corse, pp. 17-20.

Babcock R.C., Kelly S., Shears N.T., Walker J.W., Willis T.J., 1999, Changes in community structure in temperate marine reserves. Mar. Ecol. Prog. Ser. 189, 125-134.
Badalamenti F., Ramos A.A., Voultsiadou E., Sánchez-Lizaso J.L., D'Anna G., Pipitone C., Mas J., Ruiz Fernandez J.A., Whitmarsh D., Riggio S., 2000, Cultural and socio-economic impacts of Mediterranean marine protected areas. Environ. Cons. 27, 110-120.

Bain M.B., Harig A.L., Loucks D.P., Goforth R.R., Mills K.E., 2000, Aquatic ecosystem protection and restoration: Advances in methods for assessment and evaluation. Environ. Sci. Policy. 3, S89-S98.

Baine M., 2001, Artificial reefs: A review of their design, application, management and performance. Ocean Coast. Manage. 44, 241-259.

Barnabé G., Charbonnel E., Marinaro J.-Y., Ody D., Francour P., 2000, Artificial reefs in France: Analysis, assessments and prospects. In: Jensen A.C., Collins K.J., Lockwood A.P.M. (Eds.), Artificial reefs in European seas. Kluwer Academics Publishers, Dordrecht, The Netherlands, pp. 167-184.

Beaumont J., 1997, Community participation in the establishment and management of marine protected areas: A review of selected international experiences. S. Afr. Mar. Sci. 18, 333-340.

Bell J.D., 1983, Effects of depth and marine reserve fishing restrictions on the structure of a rocky fish assemblage in the northwestern Mediterranean Sea. J. Appl. Ecol. 20, 357-369.

Benedetti-Cecchi L., 2001, Beyond BACI: Optimization of environmental sampling designs through monitoring and simulation. Ecol. Appl. 11, 783-799.

Benedetti-Cecchi L., Bertocci I., Micheli F., Maggi E., Fosella T., Vaselli S., 2003, Implications of spatial heterogeneity for management of marine protected areas (MPAs): Examples from assemblages of rocky coasts in the northwest Mediterranean. Mar. Environ. Res. 55, 429-458.

Blankenship H.L., Leber K.M., 1995, A responsible approach to marine stock enhancement. Am. Fish. Soc. Symp. 15, 167-175.

Boersma P., Parrish J.K., 1999, Limiting abuse: Marine protected areas, a limited solution. Ecol. Econ. 31, 287-304.

Bohnsack J.A., 1989, Are high densities of fishes at artificial reefs the result of habitat limitation or behavioural preference? Bull. Mar. Sci. 44, 631-645.

Bohnsack J.A., 1991, Habitat structure and the design of artificial reefs. In: Bell S.S., McCoy E.D., Mushinsky H.R. (Eds.), Habitat structure - The physical arrangement of objects in space. Chapman and Hall, pp. 412-426.

Bohnsack J.A., 1993, Marine reserves. They enhance fisheries, reduce conflicts, and protect resources. Oceanus 36, 63-71.

Bohnsack J.A., 1996, Marine reserves, zoning, and the future of fishery management. Fisheries 21, 14-16.

Bohnsack J.A., Bannerot S.P., 1986, A stationary visual census technique for quantitatively assessing community structure of coral reef fishes. NOAA Tech. Rep. NMFS 41, 15 p.

Bohnsack J.A., Ecklund A.-M., Szmant A.M., 1997, Artificial reef research: Is there more than the attraction-production issue? Fisheries 22, 14-16.

Bohnsack J.A., Harper D.E., McClellan D.B., Hulsbeck M., 1994, Effects of reef size on colonization and assemblage structure of fishes at artificial reefs off Southeastern Florida, USA Bull. Mar. Sci. 55, 796-823.

Bohnsack J.A., Sutherland D.L., 1985, Artificial reef research: A review with recommendations for future priorities. Bull. Mar. Sci. 37, 11-39.

Bombace G., 1989, Artificial reefs in the Mediterranean Sea. Bull. Mar. Sci. 44, 1023-1032.

Bombace G., Fabi G., Fiorentini L., Speranza S., 1994, Analysis of the efficacy of artificial reefs located in five different areas of the Adriatic Sea. Bull. Mar. Sci. 55, 559-580. 
Botsford L.W., Morgan L.E., Lockwood D.R., Wilen J.E., 1999, Marine reserves and management of the northern California red sea urchin fishery. CalCOFI Rep. 40, 87-93.

Botsford L.W., Micheli F., Hastings A., 2003, Principles for the design of marine reserves. Ecol. Appl. 13, S25-S31.

Branden K.L., Pollard D.A., Reimers H.A., 1994, A review of recent artificial reef developments in Aust. Bull. Mar. Sci. 55, 2-3.

Brown K., Adger W.N., Tompkins E., Bacon P., Shin D., Young K., 2001, Trade-off analysis for marine protected area management. Ecol. Econ. 37, 417-434.

Caddy J.F., 2000, A fisheries management perspective on marine protected areas in the Mediterranean. Environ. Cons. 27, 98-103.

Carter D.W., 2003, Protected areas in marine resource management: Another look at the economics and research issues. Ocean Coast. Manage. 46, 439-456.

Carr M.H., 2000, Marine protected areas: Challenges and opportunities for understanding and conserving coastal marine ecosystems. Environ. Cons. 27, 106-109.

Carr M.H., Hixon M.A., 1997, Artificial reefs: The importance of comparisons with natural reefs. Fisheries 22, 28-33.

Castilla J.C., 2000, Roles of experimental marine ecology in coastal management and conservation. J. Exp. Biol. Ecol. 250, 3-21.

Chapman M.G., Underwood A.J., Skilleter G.A., 1995, Variability at different spatial scales between a subtidal assemblage exposed to the discharge of sewage and two control assemblages. J. Exp. Mar. Biol. Ecol. 189, 103-122.

Charbonnel E., Francour P., Harmelin J.-G., Ody D., Bachet F., 2000, Effects of artificial reef design on associated fish assemblages in the Côte Bleue Marine Park (Mediterranean Sea, France). In: Jensen A.C., Collins K.J., Lockwood A.P.M. (Eds.), Artificial reefs in European seas. Kluwer Academics Publishers, Dordrecht, The Netherlands, pp. 365-378.

Charbonnel E., Serre C., Ruitton S., Harmelin J.-G., Jensen A., 2002, Effects of increase habitat complexity on fish assemblages associated with large artificial reef units (French Mediterranean coast). ICES J. Mar. Sci. 59, S208-S213.

Cocklin C., Craw M., McAuley I., 1998, Marine reserves in New Zealand: Use rights, public attitudes, and social impacts. Coast. Manage. 26, 213-231.

Côté I.M., Mosqueira I., Reynolds J.D., 2001, Effects of marine reserve characteristics on the protection of fish populations: A meta-analysis. J. Fish Biol. 59, 178-189.

Dale V.H., Beyeler S.C., 2001, Challenges in the development and the use of ecological indicators. Ecol. Ind. 1, 3-10.

Denny C.M., Babcock R.C., 2004, Do partial marine reserves protect reef fish assemblages? Biol. Cons. 116, 119-129.

Department of Natural Resource and Environment, 2001, Synthesis of 3 October 2001 Workshop. Evaluating the status of Victoria's marine biodiversity: Marine protected areas. http://www.dse.vic.gov.au/web/root/domino/cm_da/ nreccm.nsf/0/feedcb035d3331e9ca256d19000b0e9f/ \$FILE/WorkshopSynthesis.pdf, p. 13

Done T.J., Reichelt R.E.L., 1998, Integrated coastal zone and fisheries ecosystem management: Generic goals and performance indices. Ecol. Appl. 8, S110-S118.

Dufour V., Jouvenel J.-Y., Galzin R., 1995, Study of a Mediterranean reef fish assemblage. Comparisons of population distributions between depths in protected and unprotected areas over one decade. Aquat. Living Resour. 8, 17-25.

Ehler C.N., 2003, Indicators to measure governance performance in integrated coastal management. Ocean Coast. Manage. 46, 335-345.
Fang L.-S., 1992, A theoretical approach of estimating the productivity of artificial reef. Acta Zool. Taiwan. 3, 5-10.

Francour P., 1994, Pluriannual analysis of the reserve effect on ichtyofauna in the Scandola natural reserve (Corsica, Northwestern Mediterranean). Oceanol. Acta 17, 309-317.

Francour P., Harmelin J.-G., Pollard D., Sartoretto S., 2001, A review of marine protected areas in the northwestern Mediterranean region: Siting, usage, zonation and management. Aquatic Conserv.: Mar. Freshw. Ecosyst. 11, 155-188.

Fraschetti S., Terlizzi A., Micheli F., Benedtti-Cecchi L., Boero F., 2002, Marine protected areas in the Mediterranean sea: Objectives, effectiveness and monitoring. Mar. Ecol. 23, 190-200.

García-Rubies A., Zabala M., 1990, Effects of total fishing prohibition on the rocky fish assemblages of Medes Islands marine reserve (NW Mediterranean). SCI. MAR. 54, 317-328.

García-Charton J.A., Pérez-Ruzafa Á., 1999, Ecological heterogeneity and the evaluation of the effects of marine reserves. Fish. Res. 42, 1-20.

García-Charton J.A., Williams I.D., Pérez-Ruzafa Á., Milazzo M., Chemello R., Marcos C., Kitsos M.-S., Koukouras A., Riggio S., 2000, Evaluating the ecological effects of Mediterranean marine protected areas: Habitat, scale and the natural variability of ecosystems. Environ. Cons. 27, 159-178.

García-Charton J.A., Pérez-Ruzafa Á., Sáanchez-Jerez P., Bayle-Sempere J.T., Reñones O., Moreno D., 2004, Multiscale spatial heterogeneity, habitat structure, and the effect of marine reserves on Western Mediterranean rocky reef fish assemblages. Mar. Biol. 144, 161-182.

Gerber L.R., Kareiva P.M., Bascompte J., 2002, The influence of life history attributes and fishing pressure on the efficacy of marine reserves. Biol. Cons. 106, 11-18.

Gerber L.R., Botsford L.W., Hastings A., Possingham H.P., Gaines S.D., Palumbi S.R., Andelman S., 2003, Population models for marine reserve design: A retrospective and prospective synthesis. Ecol. Appl. 13, S47-S64.

Grimble R., Chan M.-K., 1995, Stakeholder analysis for natural resource management in developing countries. Nat. Resour. Forum 19, 113-124.

Grossman G.D., Jones G.P., Seaman Jr. W.J., 1997, Do artificial reefs increase regional fish production? A review of existing data. Fisheries 22, 17-23.

Guénette S., Lauck T., Clark C., 1998, Marine reserves: From Beverton and Holt to the present. Rev. Fish Biol. Fish. 8, 251-272.

Guénette S., Pitcher T.J., 1999, An age-structured model showing the benefits of marine reserves in controlling overexploitation. Fish. Res. 39, 295-303.

Halpern B., 2003, The impact of marine reserves: Do reserves work and does reserve size matter? Ecol. Appl. 13, S117-S137.

Harmelin J.-G., 1999, Visual assessment of indicator fish species in Mediterranean marine protected areas. Nat. Sicil. 23, 83-104.

Harmelin J.-G., 2000, Mediterranean marine protected areas: Some prominent traits and promising trends. Environ. Cons. 27, 104-105.

Harmelin J.-G., Bachet F., Garcia F., 1995, Mediterranean marine reserves: Fish indices as tests of protection efficiency. Mar. Ecol. $16,233-250$.

Harmelin J.-G., Bellan-Santini D., 1996, Assessment of biomass and production of artificial reef communities. Proceedings of the 1st Conference of the European Artificial Reef Research Network, Ancona, Italy, March 1996. Southampton, UK: Southampton Oceanography Centre. pp. 305-322.

Hockey P.A.R., Bosman A.L., 1986, Man as an intertidal predator in Transkeï: Disturbance, community convergence and management of a natural food supply. Oikos 46, 3-14. 
Hockings M., Stolton S., Dudley N., 2000, Evaluating effectiveness: A framework for assessing the management of protected areas. IUCN World Commission on Protected Areas Best Practice Protected Area Guidelines, Series No. 6, 132 p.

IUCN - The World Conservation Union, 1988. Resolution 17.38 of the 17th General Assembly of the IUCN. Gland, Switzerland and Cambridge.

Jameson S.C., Tupper M.H., Ridley J.M., 2002, The three screen doors: Can marine "protected" areas be effective? Mar. Pol. Bull. 44, 1177-1183.

Janssen R., 1994, Multiobjective decision support for environmental management. Kluwer, Dordrecht, 248 p.

Jensen A.C., 2002a, Artificial reefs in Europe: Perspective and future. ICES J. Mar. Sci. 59, S3-S13.

Jensen A.C., 2002b, The seventh international Conference on Artificial Reefs and Related Aquatic Habitats (CARAH). ICES J. Mar. Sci. 59, S1-S2.

Jensen A.C., Collins K.J., Lockwood A.P.M., 2000, Current issues relating to artificial reefs in European seas. In: Jensen A.C., Collins K.J., Lockwood A.P.M. (Eds.), Artificial reefs in European seas. Kluwer Academics Publishers, Dordrecht, The Netherlands, pp. 489-499.

Jones G.P., Cole R.C., Battershill C.N., 1993, Marine Reserves: Do they work? In: NIWA (Ed.), The Ecology of Temperate Reefs: Proceedings of the Second International Temperate Reef Symposium, Auckland, New Zealand, pp. 29-45.

Jouvenel J.-Y., Pollard D.A., 2001, Some effects of marine reserve protection on the population structure of two spearfishing target-fish species, Dicentrarchus labrax (Moronidae) and Sparus aurata (Sparidae), in shallow inshore waters, along a rocky coast in the northern Mediterranean Sea. Aquatic Conserv.: Mar. Freshw. Ecosyst. 11, 1-9.

Kelleher G., 1996, Recent developments and announcements - A global representative system of marine protected areas. Ocean Coast. Manag. 32, 123-126.

Kelleher G., Kenchington R., 1992, Guidelines for establishing marine protected areas. A marine conservation and development report. IUCN, Gland, Switzerland, 79 p.

Konovalov S.M., 1991, Marine national parks and preservation of biological diversity. Côtes et parcs marins de la Méditerranée -

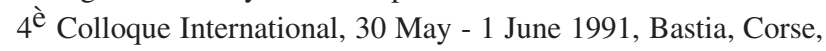
pp. 34-39.

Kramer D.L., Chapman M.R., 1999, Implications of fish home range size and relocation for marine reserves function. Environ. Biol. Fish. 55, 65-79.

Kremen C., Razafimahatratra V., Guillery R.P., Rakotomalala J., Weiss A., Ratsisompatrarivos J.-S., 1999, Designing the Masoala National Park in Madagascar based on biological and socioeconomic data. Cons. Biol. 13, 1055-1068.

Lasiak T., 1998, Multivariate comparisons of rocky infratidal macrofaunal assemblages from replicate exploited and non-exploited localities on the Transkei coast of South Africa. Mar. Ecol. Prog. Ser. 167, 15-23.

Lauck T., Clark C.W., Mangel M., Munro G.R., 1998, Implementing the precautionary principle in fisheries management through marine reserves. Ecol. Appl. 8, S72-S78.

Lindberg W.J., 1997, Can science resolve the attraction-production issue? Fisheries 22, 10-13.

Lindeman K.C. Pugliese R., Waugh G.T., Ault J.S., 2000, Developmental patterns within a multispecies reef fishery: Management applications for essential reef habitats and protected areas. Bull. Mar. Sci. 66, 929-956.
Lubchenco J., Palumbi S.R., Gaines S.D., Andelman S., 2003, Plugging a hole in the ocean: The emrging science of marine reserves. Ecol. Appl., 13, S3-S7.

Mangel M., 2000, Trade-offs between fish habitat and fishing mortality and the role of reserves. Bull. Mar. Sci. 66, 663-674.

Meinesz A., Lefevre J.R., Beurier J.-P., Boudouresque C.-F., Miniconi R., O’ Neill J., 1983, Les zones marines protégées des côtes françaises de Méditerranée. Bull. Ecol. 14, 35-50.

Murray S.N., Ambrose R.F., Bohnsack J.A., Botsford L.W., Carr M.H., Davis G.E., Dayton P.K., Gotshall D., Gunderson D.R., Hixon M.A., Lubchenco J., Mangel M., MacCall A., McArdle D.A., 1999, No-take reserve networks: Sustaining fishery populations and marine ecosystems. Fisheries 24, 11-25.

Nakamura M., 1985, Evolution of artificial fishing reef concepts in Japan. Bull. Mar. Sci. 37, 271-278.

Neigel J.E., 2003, Species-area relationships and marine conservation. Ecol. Appl., 13, S138-S145.

NOAA (National Oceanic and Atmospheric Administration), 1996, Magnuson-Stevens fishery conservation and management act, as amended through October 11, 1996, NOAA Tech. Memo. NMFS-F/SPO-23.

Ody D., Harmelin J.-G., 1994, Influence de l'architecture et de la localisation de récifs artificiels sur leurs peuplements de poisons en Méditerranée. Cybium 18, 57-70.

Osenberg C.W., St. Mary C.M., Wilson J.A., Lindberg W.J., 2002, A quantitative framework to evaluate the attraction-production controversy. ICES J. Mar. Sci. 59, S214-S221.

Palumbi S.R., 2002, Marine reserves. A tool for ecosystem management and conservation. Pew Oceans Commission, 2101 Wilson Boulevard, Suite 550. Arlington, Virginia 22201, 52 p.

Pauly D., 1998, Use of Ecopath with Ecosim to evaluate strategies for sustainable exploitation of multi-species resources. Fish. Cent. Res. Rep. 6, 15-18.

Pauly D., Christensen V., Guénette S., Pitcher T.J., Sumaila U.R., Walters C.J., Watson R., Zeller D., 2002, Towards sustainability in world fisheries. Nature 418, 689-695.

Pelletier D., 2001, Reflections on the Symposium "Spatial processes and management of marine populations". In: Kruse G. H., Bez N., Booth T., Dorn M., Hills S., Lipcius R., Pelletier D., Roy C., Smith S., Witherell D. (Eds.), Spatial processes and management of marine populations. University of Alaska Sea Grant, AK-SG00-04, Fairbanks, pp. 685-694.

Pickering H., Whitmarsh D., Jensen A., 1998, Artificial reefs as a tool to aid rehabilitation of coastal ecosystems: Investigating the potential. Mar. Pol. Bull. 37, 505-514.

Pinnegar J.K., Polunin P.V.C., Francour P., Badalamenti F., Chemello R., Harmelin-Vivien M.-L., Hereu B., Milazzo M., Zabala M., D’Anna G., Pipitone C., 2000, Trophic cascades in benthic marine ecosystems: Lessons for fisheries and protected-area management. Environ. Cons. 27, 179-200.

Pitcher T.J., Buchary E.A., Hutton T., 2002, Forecasting the benefits of no-take human-made reefs using spatial ecosystem simulation. ICES J. Mar. Sci. 59, S17-S26.

Pitcher T.J., Buchary E.A., Sumalia U.R., 2000, Spatial ecosystem simulation of no-take human-made reefs in marine protected areas: Forecasting the costs and benefits in Honk Kong. Fish. Cent. Res. Rep. 9, 146-170.

Pitcher T.J., Seaman Jr. W.J., 2000, Petrarch's Principle: How protected human-made reefs can help the reconstruction of fisheries and marine ecosystems. Fish Fish. 1, 73-81.

Planes S., Galzin R., García-Rubies A., Goñi R., Harmelin J.-G., Le Diréach L., Lenfant P., Quetglas A., 2000, Effects of marine protected areas on recruitment processes with special reference to Mediterranean littoral ecosystems. Environ. Cons. 27, 126-143. 
Polacheck T., 1990, Year round closed areas as a management tool. Nat. Res. Mod. 4, 327-354.

Polovina J.J., 1991, Fisheries applications and biological impacts of artificial habitats Artificial Habitats for Marine and Freshwater Fisheries. Academic Press, pp. 153-176.

Polovina J.J., Sakai I., 1989, Impacts of artificial reefs on fishery production in Shimamaki, Japan. Bull. Mar. Sci. 44, 997-1003.

Pomeroy C., 1999, Social considerations for marine resource management: Evidence from Big Creek Ecological Reserve. CalCOFI Rep. 40, 118-125.

Ramos-Esplà A.A., Guillén J.E., Bayle J.T., Sánchez-Jerez P., 2000, Artificial anti-trawling reefs off Alicante, south-eastern Iberian peninsula: Evolution of reef block and set design. In: Jensen A.C., Collins K.J., Lockwood A.P.M. (Eds.), Artificial Reefs in European Seas. Kluwer Academic Publishers, Dordrecht, pp. 195-218.

Rijnsdorp A.D., Pastoors M.A., 1995, Medelling the spatial dynamics and fisheries of North Sea plaice (Pleronectes platessa L.) based on tagging data. ICES J. Mar. Sci. 52, 963-980.

Roberts C.M., Polunin N.V.C., 1991, Are marine reserves effective in management of reef fisheries? Rev. Fish Biol. Fish. 1, 65-91.

Roberts C.M., Polunin N.V.C., 1993, Marine reserves: Simple solutions to managing complex fisheries? Ambio 22, 363-368.

Rogers C.S., Beets J., 2001, Degradation of marine ecosystems and decline of fishery resources in marine protected areas in the US Virgin Islands. Environ. Cons. 28, 312-322.

Rowley R.J., 1994, Case studies and reviews - Marine reserves in fisheries management. Aquat. Conserv.: Mar. Freshw. Ecosyst. 4, 233-254.

Russ G.R., Alcala A.C., 1996, Do marine reserves export adult fish biomass? Evidence from Apo island, Central Philippines. Mar. Ecol. Prog Ser. 132, 1-9.

Russ G.R., 2002, Yet another review of marine reserve as reef fishery management tools. In Sale P.F. (Ed.), Coral reef fishes: Dynamics and diversity in a complex ecosystem. Academic Press, San Diego, 2002, 421-443.

Salmona P., Verardi D., 2001, The marine protected area of Portofino, Italy: A difficult balance. Ocean Coast. Manag. 44, 39-60.

Samples K.C., Sproul J.T., 1985, Fish aggregating devices and openaccess commercial fisheries: A theoretical inquiry. Bull. Mar. Sci. 34, 305-317.

Sánchez-Lizaso J.L., Goñi R., Reñones O., García-Charton J.A., Galzin R., Bayle J.T., Sánchez-Jerez P., Pérez-Ruzafa A., Ramos A.A., 2000, Density dependence in marine protected populations: A review. Environ. Cons. 27, 144-158.

Santos M.N., Monteiro C.C., Erzini K., 1995a, Comparison of natural reef and artificial reef fish assemblages in Algarve waters (south Portugal). In: Secretariat, E.C. (Ed.), International Conference on Ecological System Enhancement Technology for Aquatic Environments. Japan International Marine Science and Technology Federation, Tokyo, Japan, pp. 210-214.

Santos M.N., Monteiro C.C., Lassèrre G., 1995b, A four year overview of the fish assemblages and yield on two artificial reef systems off Algarve (south Portugal). Proceedings of the 30th European Marine Biological Symposium, Southampton, UK, pp. 345-352.

Santos M.N., Monteiro C.C., Lassèrre G., 1996, Finfish attraction and fisheries enhancement on artificial reefs: A review. Proceedings of the 1st Conference of the European Artificial Reef Research Network, Ancona, Italy, pp. 18.

Schwartz M.W., 1999, Choosing the appropriate scale of reserves for conservation. Ann. Rev. Ecol. Syst. 30, 83-108.

Seaman Jr. W.J., 1996, Does the level of design influence success of an artificial reef? Proceedings of the 1st Conference of the European Artificial Reef Research Network, Ancona, Italy, pp. 13.

Seaman Jr. W.J., 2002, Unifying trends and opportunities in global artificial reef research, including evaluation. ICES J. Mar. Sci. 59, S14-S16.

Shafer C.L., 1999, National park and reserve planning to protect biological diversity: Some basic element. Landscape and Urban Plan. 44, 123-153.

Steimle F.W., Meier M.H., 1997, What information do artificial reef managers really want from fishery science? Fisheries 22, 6-8.

St-Mary C.M.S., Osenberg C.W., Frazer T.K., Lindberg W.J., 2000, Stage structure, density dependence and the efficacy of marine reserves. Bull. Mar. Sci. 66, 675-690.

Sumaila U.R., Guénette S., Alder J., Chuenpagdee R., 2000, Addressing ecosystem effects of fishing using marine protected areas. ICES J. Mar. Sci. 57, 752-760.

Tuya F.C., Soboil M.L., Kido J., 2000, An assessment of the effectiveness of marine protected areas in the San Juan Islands, Washington, USA. ICES J. Mar. Sci. 57, 1218-1226.

Underwood A.J., 1981. Techniques of analysis of variance in experimental marine biology and ecology. Oceanogr. Mar. Biol. Ann. Res. 19, 513-605.

Underwood A.J., 1992, Beyond BACI: The detection of environmental impacts on populations in the real, but variable, world. J. Exp. Mar. Biol. Ecol. 161, 145-178.

Underwood A.J., 1993, The mechanics of spatially replicated programmes to detect environmental impacts in a variable world. Austr. J. Ecol. 18, 99-116.

Underwood A.J., 2003, Power, precaution, Type II error and sampling design in assessment of environmental impacts. J. Exp. Mar. Biol. Ecol. 296, 49-70.

Walters C., Pauly D., Christensen V., 1999, Ecospace: Prediction of mesoscale spatial patterns in trophic relationships of exploited ecosystems, with emphasis on the impacts of marine protected areas. Ecosystems 2, 539-554.

Ward T.J., Vanderklift M.A., Nicholls A.O., Kenchington R.A., 1999, Selecting marine reserves using habitats and species assemblages as surrogates for biological diversity. Ecol. Appl. 9, 691-698.

Watson R., Alder J., Walters C., 2000, A dynamic mass-balance model for marine protected areas. Fish Fish. 1, 94-98.

White A.T., Loke C.M., De Silva M.W.R.N., Guarin F.Y., 1990, Artificial reefs for marine habitat enhancement in Southeast Asia, Manila, Philippines. ICLARM Educ. Ser. 11, 45 p.

Whitmarsh D., Pickering H., 1995, Economic appraisal of artificial reefs: Case-study. CEMARE Res. Pap., 85, 9

Whitmarsh D., Pickering H., 1997, Commercial exploitation of artificial reefs: Economic opportunities and management imperatives. CEMARE Res. Pap., 115, 19

Zalmon I.R., Novelli R., Gomes M.P., Faria V.V., 2002, Experimental results of an artificial reef programme on the Brazilian coast north Rio de Janeiro. ICES J. Mar. Sci. 59, S83-S87. 